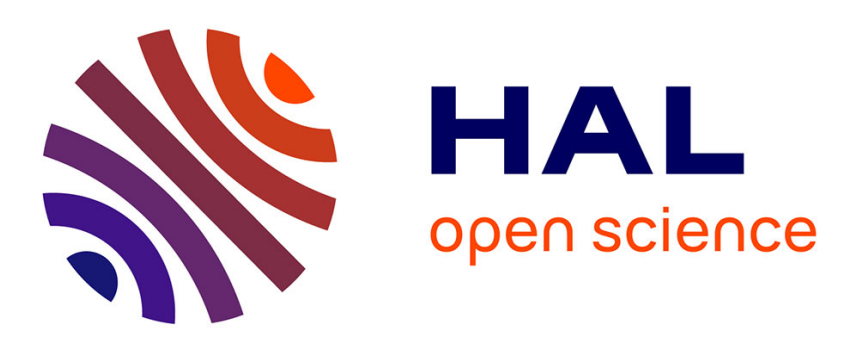

\title{
Relationship between locomotor activity, environmental factors, and timing of the spawning migration in the European eel, Anguilla anguilla
}

Caroline M. F. Durif, F. Travade, Jacques Rives, Pierre Elie, Claude Gosset

\section{- To cite this version:}

Caroline M. F. Durif, F. Travade, Jacques Rives, Pierre Elie, Claude Gosset. Relationship between locomotor activity, environmental factors, and timing of the spawning migration in the European eel, Anguilla anguilla. Aquatic Living Resources, 2008, 21 (2), pp.163-170. 10.1051/alr:2008031 . hal-02590605

\section{HAL Id: hal-02590605 \\ https://hal.inrae.fr/hal-02590605}

Submitted on 31 May 2020

HAL is a multi-disciplinary open access archive for the deposit and dissemination of scientific research documents, whether they are published or not. The documents may come from teaching and research institutions in France or abroad, or from public or private research centers.
L'archive ouverte pluridisciplinaire HAL, est destinée au dépôt et à la diffusion de documents scientifiques de niveau recherche, publiés ou non, émanant des établissements d'enseignement et de recherche français ou étrangers, des laboratoires publics ou privés.

$$
\text { Copyright }
$$




\title{
Relationship between locomotor activity, environmental factors, and timing of the spawning migration in the European eel, Anguilla anguilla
}

\author{
Caroline M.F. Durif ${ }^{1,4, a}$, Francois Travade ${ }^{2}$ Jacques Rives $^{3}$, Pierre Elie $^{4}$ and Claude Gosset ${ }^{3}$ \\ ${ }^{1}$ Institute of Marine Research-Austevoll, 5392 Storeb / Department of Biology, University of Oslo, PO Box 1066 Blindern, \\ 0316 Oslo, Norway \\ 2 EDF, Études et Recherches, 6 quai Watier, 78401 Chatou Cedex, France \\ 3 INRA, Laboratoire d'Ecologie des Poissons, BP 3, 64310 Saint-Pée-sur-Nivelle, France \\ ${ }^{4}$ Cemagref, Research unit: Estuarine ecosystems and migratory amphihaline fish species, 50 avenue de Verdun, 33612 Cestas, France
}

Received 19 March 2008; Accepted 30 April 2008

\begin{abstract}
At the onset of sexual maturation, European eels Anguilla anguilla exhibit high locomotor activity which may correspond to migratory restlessness. We measured activity of captive eels and determined whether it correlated with downstream runs of silver eels as well as changes in environmental factors. Groups of eels at different stages of the silvering process (yellow to silver stage) were tagged and placed in separate tanks supplied with either river or tap water. Activity was measured by means of a flat-board antenna placed vertically in the middle of the tank at the surface of the water. Wild migrating silver eels were caught in the nearby river. Activity of eels in the river water tanks increased 1 to 2 days before downstream migrating eels were caught in the trap, and concurrently with a rise in turbidity and a decrease in conductivity. Activity of eels in the tap water tank showed a different pattern, which did not correspond to downstream runs. A peak in activity corresponded to a drop in tap water $\mathrm{pH}$. It is concluded that eels do show periods of high locomotor activity at the onset of migration and this could be used to predict downstream migration. Movements are triggered by changes in water composition (as opposed to changes in discharge, atmospheric pressure and lunar cycle) measured using turbidity and/or conductivity as proxies. If eels are able to detect such small changes in water conductivity $\left(80 \mu \mathrm{S} \mathrm{cm}^{-1}\right)$, they may use it to find their way to the estuary.
\end{abstract}

Key words: Locomotor activity / Downstream migration / Environmental factors / Prediction / Anguilla anguilla / Atlantic Ocean

Résumé - Relation entre l'activité locomotrice, les facteurs environnementaux et leur synchronisation avec la
migration d'avalaison chez l'anguille européenne, Anguilla anguilla. Au tout début de leur maturation sexuelle,
les anguilles européennes, Anguilla anguilla, présentent une forte agitation qui pourrait correspondre aux premiers
mouvements migratoires. L'objectif de cette étude est de déterminer si ces périodes d'activité correspondent aux pics
de dévalaison d'anguilles argentées en rivière et si elles peuvent être associées aux variations de certains facteurs
environnementaux. Plusieurs lots d'anguilles (stades jaune et argenté) ont été marqués et placés dans des bassins
séparés, alimentés soit en eau de la rivière, soit en eau de ville. L'activité des anguilles est mesurée par l'intermé-
diaire d'une antenne de détection située verticalement au milieu du bassin, près de la surface. Un piège de dévalai-
son permet de capturer les anguilles en migration dans la rivière. L'activité des anguilles en bassins alimentés par
la rivière ont une activité accrue 1 à 2 jours avant la capture d'anguilles de dévalaison dans le piège et ces périodes
correspondent à une augmentation de la turbidité et à une diminution de la conductivité. Les individus dans le bas-
sin eau de ville présentent un comportement différent et l'unique pic d'activité correspond à une baisse du pH. En
conclusion, les anguilles montrent bien des périodes d'activité intense au moment de la dévalaison et ceci pourrait
être utilisé pour prévoir les pics de dévalaison. Les mouvements sont déclenchés par des variations dans la compo-
sition de l'eau de la rivière (par opposition à des variations de débit, de pression atmosphérique et au cycle lunaire)

a Corresponding author: caroline.durif@imr.no 
dvisibles à travers les changements de turbidité et/ou de conductivité. Si les anguilles sont capables de percevoir des variations aussi faibles de conductivité $\left(80 \mu \mathrm{S} \mathrm{cm}^{-1}\right)$, ceci pourrait constituer un signal pour l'orientation vers l'aval.

\section{Introduction}

Migrations occur at specific times in the life of a fish. In eels, feeding and breeding areas are separated by several thousand $\mathrm{km}$. Spawning takes place once in a lifetime and, therefore, eels are strongly constrained to synchronize their migration. All European eels (Anguilla anguilla L.) spawn in the Sargasso Sea (Schmidt 1922), but the growth period of the life history - the yellow eel stage (5-25 years) - is spent in either sea-, brackish, or freshwater environments. After this period, eels become silver: they change from a resident, feeding, usually freshwater fish into a migratory, non-feeding, marine adapted fish. For A. anguilla, this takes place during the summer and external changes become apparent as eels start to swim (Durif et al. 2005; van Ginneken et al. 2007). These sexually maturing individuals head back to the Sargasso Sea to spawn where they then presumably die. Silver eels migrate downstream from inland waters in late summer and autumn under the influence of environmental factors usually associated with flood conditions and low light level (Durif and Elie 2008; Bruijs and Durif in press), but the exact nature of these factors has not been determined. A sudden drop in temperature is associated with increased locomotor activity of silver eels, but not yellow eels (Westin and Nyman 1979), and spawning downstream migration usually occurs during periods of decreasing temperature (Vøllestad et al. 1986). Migratory events have been linked to increase in discharge and rainfall events (for review, Haro 2003), but also to atmospheric depression (Okamura et al. 2002). Eels migrate more often during the last quarter of the lunar cycle and avoid migrating during the full moon (Boëtius 1967; Haraldstad et al. 1985; Euston et al. 1997). However, there is seemingly contradictory evidence that silver eels may descend rivers during daytime or after a full moon (Behrmann-Godel and Eckmann 2003), with rising temperature (Sloane 1984), and with low or no discharge (Euston et al. 1997).

In 2001, the ICES Working Group on Eels identified a need to document and describe cost-effective technologies to allow safe and effective downstream passage of eels at hydropower stations (ICES 2007). Turbine entrainment causes massive direct and indirect mortality of silver eels (Hadderingh and Baker 1998; EPRI 2001; Winter et al. 2006). Reducing or ceasing turbine activity during the period that eels migrate downstream is considered as one of the most cost-effective means of reducing mortality. At the time of migration, silver eels are said to display increased locomotor activity or "migratory restlessness" (Lowe 1952). Observations of the locomotor activity of captive silver eels is used by fishermen to decide when to cast their nets (Fontaine 1975). However, definitive evidence that this increased activity is associated with a migratory urge is lacking.

The goals of the present study were to generate evidence that locomotor activity of confined silver eels is related to migratory behavior and to determine which environmental factor(s) eels react to.

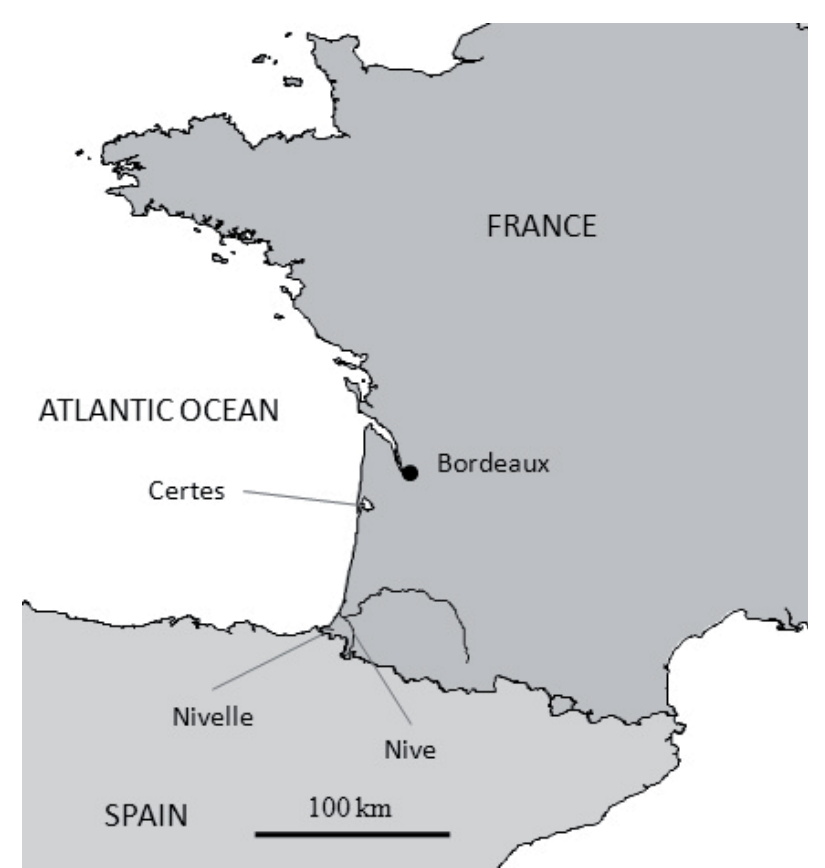

Fig. 1. Location of sites mentioned in the text. Certes (Atlantic coast) is a brackish water marsh where a group of eels were captured. Activity tanks were located either on the River Nive or on the River Nivelle (SW France).

\section{Material and methods}

\subsection{Monitoring of eel activity}

Experiments were conducted at the hydroelectric power station of Halsou in France. The power station is located about $23 \mathrm{~km}$ from the sea on the River Nive (Fig. 1). Eels were kept in 4 different outdoor tanks on the grounds of the EDF (Electricité de France) site (Fig. 2). Square tanks (side length $1 \mathrm{~m}$, height $0.5 \mathrm{~m}$ ) were used in all experiments (Fig. 3). Water level was set at $0.25 \mathrm{~m}$. The inflow was located $0.45 \mathrm{~m}$ above the water level. The tanks were covered with wooden boards in three experiments. These boards had small fenced openings $(20 \times 20 \mathrm{~cm})$ that were covered during the experiments. However light may have been perceptible through cracks or along the edges. To obtain information on the behavior of eels during their bursts of activity, a video camera was installed above one of the tanks, leaving it uncovered. A flat board antenna (length $1 \mathrm{~m}$, height $0.3 \mathrm{~m}$, width $0.05 \mathrm{~m}$ ) was mounted on a wooden support and fitted inside the tank so that the above-surface part measured approximately $0.05 \mathrm{~m}$. The antenna was connected to an automatic recording device (Trovan), that detected PITtags at a distance of approximately $0.05-0.06 \mathrm{~m}$. Clay tiles were placed in all tanks to provide shelters for the eels.

Water was pumped into the tanks either directly from the public water network (Nive2-00) or from the River Nive (tanks Certes-99, Nive-99, and Nive1-00). Eels from one of the tanks (Nive-99) were held for 5 months beyond the usual 


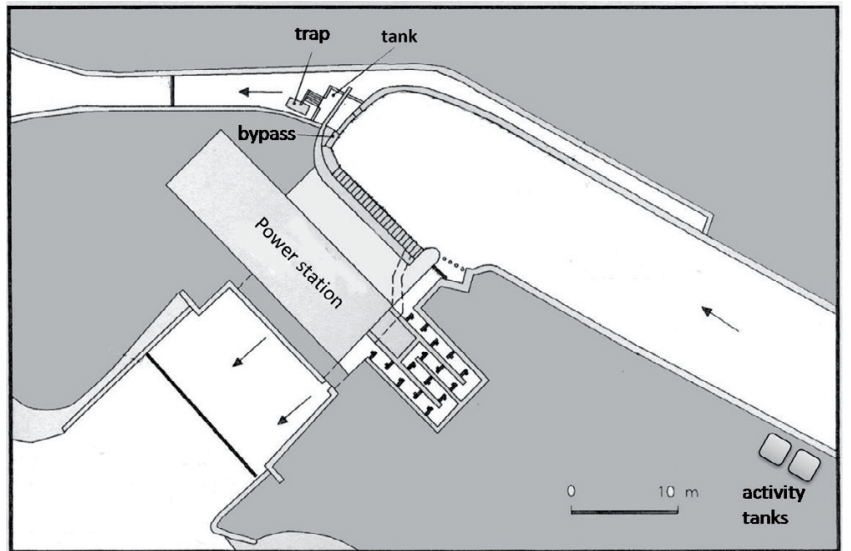

Fig. 2. Top view of the power plant area where the trap and activity tanks were installed.

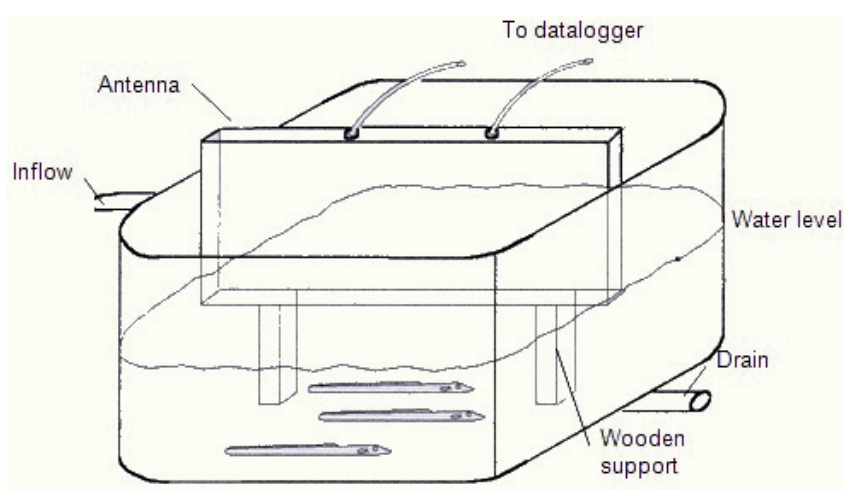

Fig. 3. Schematic drawing of the activity tank.

downstream migration season (December 1999 to April 2000). This group was transferred in January 2000 to the INRA biological station $18 \mathrm{~km}$ away (Fig. 1) where it was then supplied with water from the River Nivelle.

The first set of experiments ran from November 1999 to April 2000 (Table 1). Downstream spawning migration usually starts in October and experiments began when a sufficient number of silver eels were caught. The second year, it was possible to start earlier (experiments ran from October 2000 to January 2001), because eels were caught by electrofishing in September.

Monitored eels originated either from the coastal marsh of Certes (Fig. 1) or directly from the River Nive. Eels from Certes were caught during their seaward migration using a weir trap. Eels from the River Nive were obtained either by electrofishing prior to the migratory season in September or using a trap specifically installed to capture downstream migrating eels (see Sect. 2.3).

After their capture, eels were taken directly to the experimental facility without any acclimation period for the brackish water eels (Certes). They were anaesthetized with a 1:10 solution of clove oil diluted in ethanol (70\%). A PIT-Tag was inserted in the dorsal muscle of each fish. Each eel was measured for length, weight, pectoral fin length, vertical and horizontal eye diameters. These measurements were used to determined stage according to Durif et al. (2005; in press): stage I and II (yellow); III (pre-migrant); IV and V (silver).

\subsection{Monitoring of spawning downstream migration}

A trap was installed at the outlet of a bypass system near the intakes of the power station (Fig. 2). Fish first entered the bypass built against the spillway, then fell into a tank built at the outlet of the spillway and then into a trap. Eels were collected from the trap twice a day, morning and evening. The trap operated between 7 October and 6 December 1999 and from 27 September to 13 December 2000. Description of the power plant, and complete details of the trap, are given elsewhere (Durif et al. 2003; Gosset et al. 2005).

\subsection{Measurement of environmental parameters}

Water temperature, conductivity, turbidity, and discharge in the power canal were recorded continuously (every $4 \mathrm{~min}$ ). Sensors were placed in the River Nive, a few meters away from the tanks. Sensors were also placed in the tap water tank to measure turbidity and temperature. Overall discharge in the River Nive was obtained from the DDE (Direction Départementale de l'Equipement). Barometric air pressure was obtained from Météo-France for the year 2000 only. Discharge, water temperature, conductivity were recorded on the River Nivelle after eels were transferred. Turbidity was also measured, but these data were discarded due to faulty equipment. All data are presented with collection time (GMT).

Pearson's correlations were calculated with a Bonferroni test. $P<0.05$ was considered statistically significant. The adaptation periods were removed for calculation of correlations because these periods corresponded to 2-3 days of high agitation after placing the eels in the tanks (Certes-99: 11 to 13 November; Nive1-00: 29 September to 3 October; Nive-99: 30 November to 1 December). Rayleigh tests, as described in Batschelet (1981), were used to determine if activity was statistically higher at a certain time of day.

\section{Results}

\subsection{General behavior of eels in tanks}

Activity of eels was high during the first 2-3 days after they were placed into the tank. After this acclimation period, they only showed peaks of activity during specific periods, and hid under the clay tiles the rest of the time. Video observations showed that during active periods, eels would either swim in circles along the walls of the tanks at moderate speed or try to escape by propelling themselves above surface level towards the water inflow. A third type of behavior was observed where eels rubbed against hard surfaces (shelters or antenna). This was associated with the appearance of Ichtyophtirius multifiliis infections which produced white visible cysts on the fish.

Eels displayed a clear circadian rhythm in all four tanks. They were active mostly at night. Distribution of daily activity counts was non-uniform in all 4 tanks ( $p<0.05$, Raleigh test). Periods of maximum activity were different in the open and closed tanks. Activity increased gradually in the open tank and peaked at 19:00. Highest mean activity took place at 21:00 in this tank (Nive1-00; Rayleigh test $r=0.47, p<0.05$ ). The 
Table 1. Characteristics of tanks and associated eels.

\begin{tabular}{|c|c|c|c|c|c|c|c|}
\hline Tanks & $\begin{array}{c}\text { Light } \\
\text { treatment }\end{array}$ & $\begin{array}{c}\text { Water } \\
\text { treatment }\end{array}$ & Start date & $\begin{array}{l}N \text { of } \\
\text { days }\end{array}$ & Stage & $N$ & $\begin{array}{l}\text { Mean length } \pm \text { SD } \\
\text { of eels }(\mathrm{mm})\end{array}$ \\
\hline ¿ू. & Covered & River & 11 Nov. 1999 & 32 & Silver & 10 & $390 \pm 15$ \\
\hline 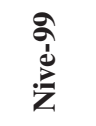 & Covered & River & 30 Nov. 1999 & 152 & Silver & 10 & $696 \pm 54$ \\
\hline \multirow{3}{*}{$\frac{\substack{1 \\
\grave{2}}}{2}$} & \multirow{3}{*}{ Uncovered } & \multirow{3}{*}{ River } & & \multirow{3}{*}{$35-60$} & Yellow & 3 & $518 \pm 45$ \\
\hline & & & $\begin{array}{l}29 \text { Sep. } 2000 \text { and } 24 \\
\text { Oct. } 2000 \text { ( } 3 \text { eels })\end{array}$ & & Premigrant & 4 & $647 \pm 48$ \\
\hline & & & & & Silver & 6 & $665 \pm 29$ \\
\hline \multirow{3}{*}{ 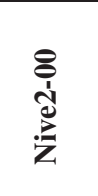 } & \multirow{3}{*}{ Covered } & \multirow{3}{*}{ Tap } & & \multirow{3}{*}{$77-102$} & Yellow & 2 & 555 and 590 \\
\hline & & & $\begin{array}{l}29 \text { Sep. } 2000 \text { and } 24 \\
\text { Oct. } 2000 \text { (3 eels) }\end{array}$ & & Premigrant & 3 & $572 \pm 23$ \\
\hline & & & & & Silver & 6 & $620 \pm 80$ \\
\hline
\end{tabular}

maximum mean period of activity occurred later in the closed tanks, at respectively 22:56 (Rayleigh test $r=0.59, p<0.05$ ), 23:13 (Rayleigh test $r=0.49, p<0.05$ ), and 23:44 (Rayleigh test $r=0.63, p<0.05)$ in the Nive-99, Certes-99, and Nive200 tanks.

\subsection{Comparison of tank activity and spawning downstream migration}

One hundred and forty three silver eels were caught in the trap over the whole study period (in 1999: 68 eels; in 2000: 75 eels). The number of eels caught in the trap and the activity of eels in the tank were closely related (Fig. 4). During the first year (Fig. 4, top panel), eels were caught in the trap between 14 and 21 November, and $76 \%$ of the catches occurred within 3 nights $(15,16$, and 20 November). Activity of eels in the tank (Certes-99) was maximal on 13, 15, and 19 November, thus approximately 1 day before the downstream runs of wild eels. There was a significant correlation when a lag of $1 \mathrm{~d}$ was applied $(R=0.90, p<0.05)$. Activity decreased on 15 and until 17 November as did the number of eels in the trap with a $1 \mathrm{~d}$ lag. There was no activity and no migration after 20 November and until the end of the experiment on 29 November.

The same trends were observed the following year (Fig. 4, bottom panel). Most migratory eels that year were caught between 13 and 25 October. The main peaks of activity recorded in the tanks were followed, approximately 2 days later, by captures of migrants in the trap. There was a significant correlation when a lag of $2 \mathrm{~d}$ was applied $(R=0.42, p<0.05)$. Activity in the tank was then reduced until 18 November, when eels became agitated again in association with a second wave of downstream migration.

Eels from the Nive2-00 batch (tap water) exhibited only one period of intense activity from 28 October to 5 November, which did not correspond to downstream movement of eels in the river (Fig. 4, top panel).

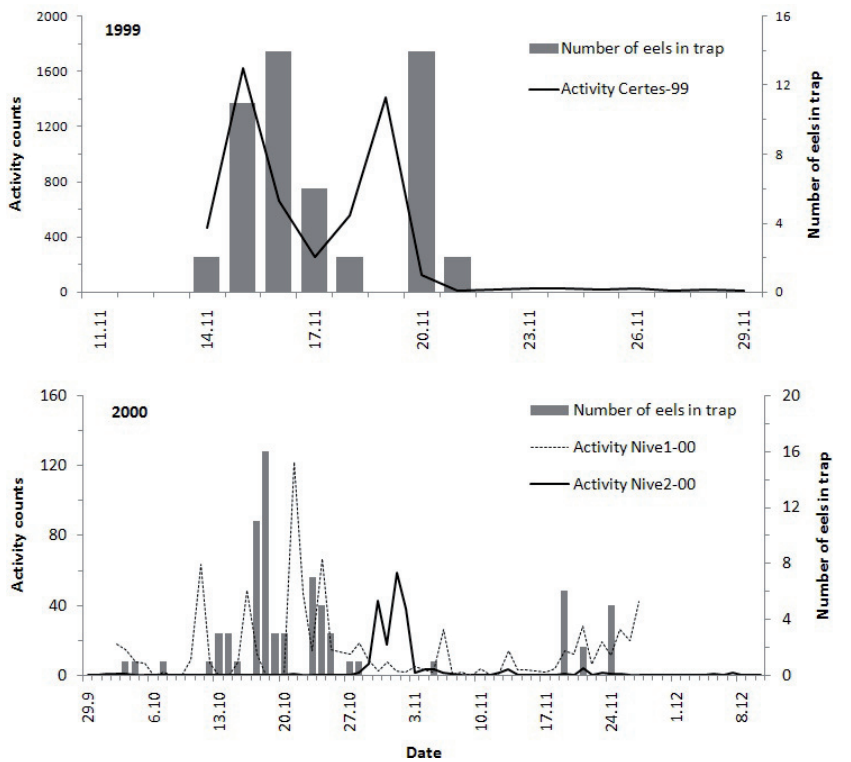

Fig. 4. Counts of activity of eels in 1999 (top panel) and 2000 (bottom panel) in comparison with the number of eels caught in the trap. Certes-99 and Nive1-00 tanks were supplied with river water while the Nive2-00 tank was supplied with tap water. Activity counts of Nive2-00 eels were divided by 10 for scaling purposes.

\subsection{Environmental parameters and tank activity}

Eel activity was always lowest around the full moon but occurred during the 3 other moon phases. Activity was maximum around the last quarter (47\% of total activity) in tank Nive-99, during the first quarter (78\%) in tank Certes-99, and around the new moon $(50 \%)$ in tank Nive1-00. There was no significant difference in tank Nive2-00 ( $X^{2}$ test: $\left.p=0.81\right)$.

Activity counts of eels in river water (Nive-99, and Nive1$00)$ were highly correlated with turbidity and conductivity (Table 2, Fig. 5). The correlation with conductivity was not 
Table 2. Summary of correlations (Rand $p$ value) between activity of eels in the different treatment-tanks and environmental factor in 1999 and 2000. Mean \pm SD and minimum and maximum values of environmental factors are given for the number of days of monitoring $(N)$; na: not avalailable.

\begin{tabular}{|c|c|c|c|c|c|}
\hline Treatment & $\begin{array}{c}N \\
\text { (days) }\end{array}$ & Mean \pm SD & [Min-Max] & $\boldsymbol{R}$ & $p$ value \\
\hline \multicolumn{6}{|l|}{ Turbidity (NTU) } \\
\hline Certes-99 & 16 & $11.1 \pm 11.1$ & $0-65$ & 0.94 & $p<0.001$ \\
\hline Nive-99 River Nive & 14 & $15.5 \pm 18.2$ & $0-98.7$ & 0.75 & 0.013 \\
\hline River Nivelle & 136 & na & na & $0.71 *$ & $p<0.001$ \\
\hline Nive1-00 & 57 & $54.3 \pm 73.4$ & $5-702$ & 0.67 & $p<0.001$ \\
\hline Nive2-00 & 72 & $0.1 \pm 0.1$ & $0-0.30$ & -0.13 & 0.29 \\
\hline \multicolumn{6}{|l|}{ Conductivity $\left(\mu \mathrm{S} \mathrm{cm}^{-1}\right)$} \\
\hline Certes-99 & 16 & $193 \pm 21$ & $120-225$ & -0.49 & 0.32 \\
\hline Nive-99 River Nive & 14 & $196 \pm 22$ & $130-219$ & -0.69 & 0.039 \\
\hline River Nivelle & 136 & $191 \pm 27$ & $123-234$ & -0.49 & $p<0.001$ \\
\hline Nive1-00 & 57 & $183 \pm 26$ & $113-246$ & -0.49 & 0.001 \\
\hline \multicolumn{6}{|l|}{ Temperature $\left(\mathrm{C}^{\circ}\right)$} \\
\hline Certes-99 & 16 & $10.2 \pm 0.3$ & $9.9-10.7$ & 0.73 & 0.008 \\
\hline Nive-99 River Nive & 14 & $8.3 \pm 1.1$ & $6-10.4$ & 0.50 & 0.43 \\
\hline River Nivelle & 136 & $10.1 \pm 2.2$ & $4-15$ & 0.21 & 0.15 \\
\hline Nive1-00 & 57 & $12.2 \pm 1.6$ & $8.8-15$ & 0.26 & 0.55 \\
\hline Nive2-00 & 72 & $13.4 \pm 1.9$ & $7.3-21$ & 0.13 & 1 \\
\hline \multicolumn{6}{|l|}{ Atmospheric pressure $(\mathrm{hPa})$} \\
\hline Nive1-00 & 57 & $1012 \pm 8$ & 989-1027 & -0.002 & 1 \\
\hline Nive2-00 & 72 & $1011 \pm 9$ & $986-1027$ & -0.14 & 1 \\
\hline \multicolumn{6}{|l|}{$p H$} \\
\hline Nive2-00 & 72 & $7.5 \pm 0.2$ & $6.8-7.7$ & -0.23 & 0.83 \\
\hline
\end{tabular}

*Correlation with discharge as a proxy for turbidity (see text).

statistically significant in the Certes-99 tank. Only the Certes99 tank showed a correlation with water temperature.

Nive-99 eels were held for an additional 5 months at the biological station on River Nivelle. Eels continued to show bursts of activity beyond the usual migration season (Fig. 5, bottom panel). However, these periods of activity were less frequent than during the first period. There were technical problems with the turbidity measurements on the River Nivelle, so discharge (measured near the tank from the River Nivelle) was used as a proxy since both parameters were highly correlated $(R=0.9, p<0.05)$. Discharge per se could not be directly perceived by the eels in the tank. The correlations of activity with discharge and conductivity were highly significant (Table 2).

Activity counts of eels in the tap water tank (Nive2-00) did not correlate with any environmental factors. Data from the water company indicated a drop in $\mathrm{pH}$ just before eels were agitated (Fig. 6).

\subsection{Activity level and stage of eels}

There were large differences in total activity between tanks. Relative activity was counted as the total number of activity counts over the number of days spent in the tank. Eels were 11 times more active in 1999 than in 2000. Relative activity was highest in the Certes-99 group, which originally came from brackish water. For the same period, 30 November 1999 to 13 December 1999 , Certes-99 eels had a relative activity of 295, whereas Nive-99 eels had a relative activity of 180 .

Differences in relative activity were also found among eels of different stages. Stage V eels (silver eels) were always the most active. They were responsible for $80 \%$ of the activity in the tap water tank (Nive2-00). Stage III eels (pre-migrants) also moved during the same periods but less intensively. Eels at stage II (yellow eels) were more active at the start of the experiment, during the acclimation period. Their activity was significantly correlated with temperature $(R=0.45, p<0.001)$ and greatly reduced at temperatures under $12{ }^{\circ} \mathrm{C}$.

\section{Discussion}

Eels held in captivity showed distinct periods of high locomotor activity corresponding, with 1-2 day lag, to natural downstream migration of eels in the nearby river. This confirms that locomotory activity is related to migratory behavior. Activity occurred even with shelters in the tanks, despite the fact that these reduce total activity (Edel 1975). The delay between activity peaks and captures of wild eels may have corresponded to the distance swam by eels in the river after their first movements. In the tank, the flat board antenna was located at the surface of the water, and therefore only escape behavior (as opposed to movements between shelters) was recorded. Moreover, observations from videos confirmed that periods of recorded high activity corresponded to eels trying to escape the tank by aiming for the inflow.

A clear diel rhythm was found in all tanks and activity was higher at night, which is the usual period for eel downstream migration. Mean time of highest activity was earlier in the uncovered tank (21:00) than in the covered tank (around 0:00) where light changes were less perceptible. Eels, like many 

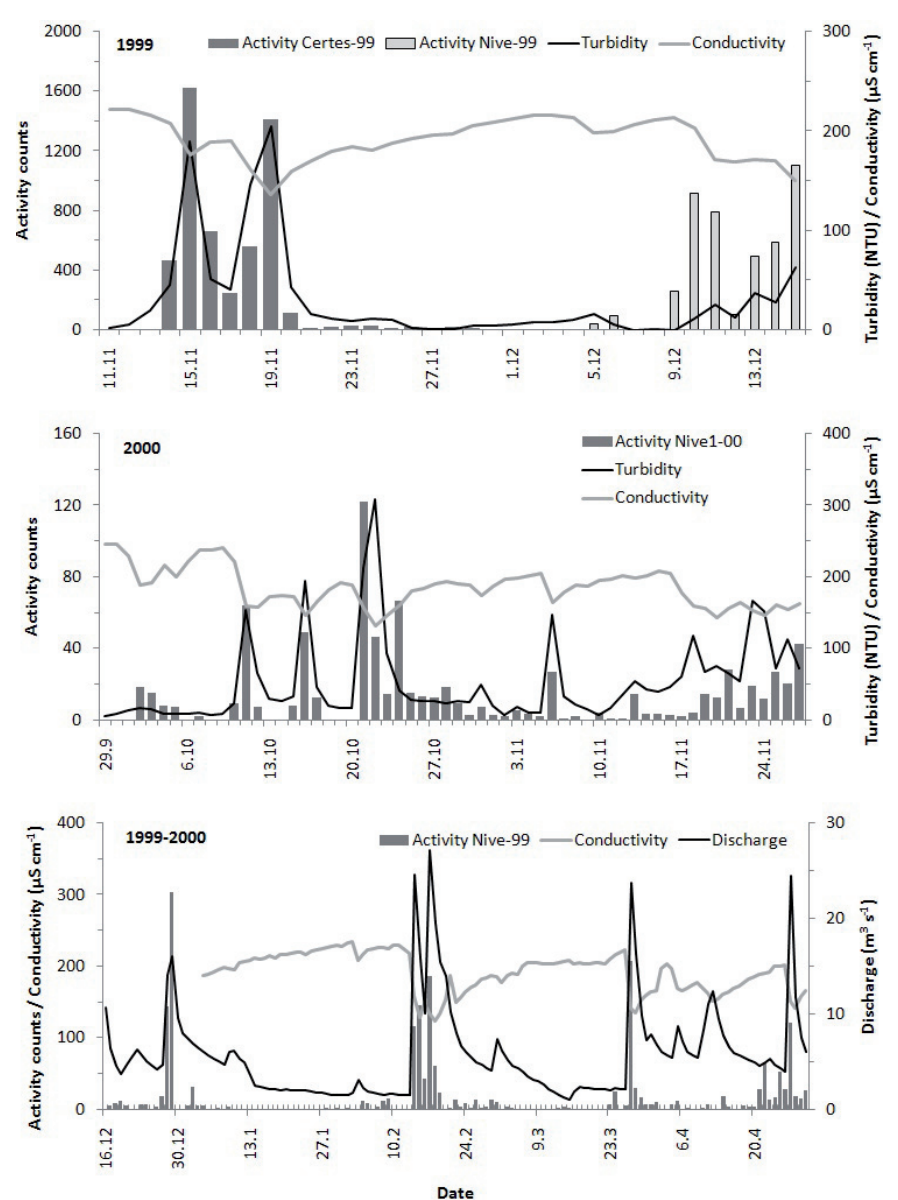

Fig. 5. Counts of activity of eels in 1999 and 2000 in comparison with environmental factors measured on the River Nive (top and middle panel) and the River Nivelle (bottom panel).

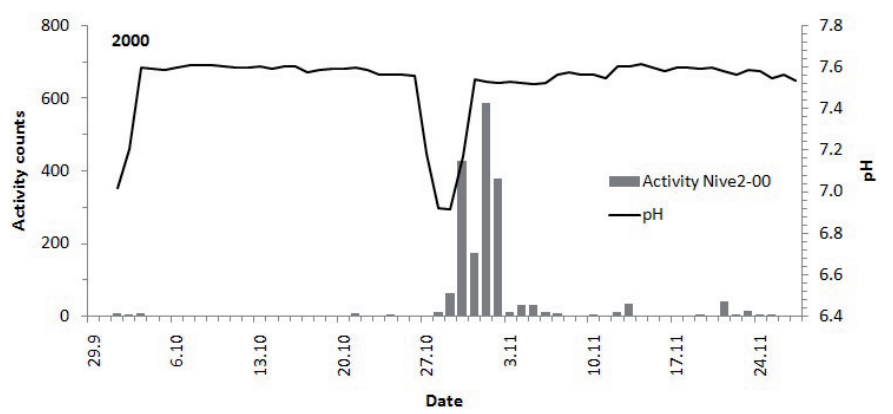

Fig. 6. Counts of activity of the eels held in tap water and variations in $\mathrm{pH}$ given by the public water network.

other nocturnal animals, typically show crepuscular peaks of activity (Edel 1976). In the present study, only eels in the uncovered tank showed crepuscular peaks, suggesting that eels reacted to the transition in light intensity.

Activity of silver eels (stage V) was significantly higher than yellow eels. Although yellow eels were agitated, this was mainly in the beginning when individuals were placed into the tank. Yellow eels moved at the same time as silver eels but activity was reduced when temperature decreased. Low temperatures decrease activity in yellow eels and cause them to significantly decrease feeding activity in winter (Tesch 2003). Thus, in this study, above a certain temperature threshold, activity periods in both yellow and silver eels occur under the same environmental conditions. Yellow eels forage for food at night and under dark and turbid conditions (Tesch 2003). At the silver stage, migration is prioritized over feeding activity.

Downstream spawning migration of eels is frequently associated with increases in river discharge (Haro 2003; Bruijs and Durif in press). The present results indicate that eels respond to chemical cues emanating from such changes in flow or water level rather than to the mechanical stimulus. Activity periods of eels held in river and tap water were different. It follows, therefore, that eels reacted to something in the water rather than in the air and thus neither atmospheric pressure nor moon phases were responsible for the increased locomotor activity. Temperature variations were also the same in the river and tap water tank and, therefore, this parameter could not have been responsible for the individual peaks of activity. Pheromones from previously migrating individuals have been suggested as potential cues (Smith 1985). However, the fact that confined eels moved 1 to 2 days before actual migration refutes this hypothesis. Also, eels kept beyond migration season, when the probability of eels migrating in the river was very low, continued to show discrete periods of activity. These observations suggest that eels reacted directly to changes in the water quality (turbidity and/or conductivity) as there was no delay between their activity and changes in turbidity and conductivity. Eels have an extremely well developed olfactory sense (Sola et al. 1993). Silver eels can discriminate and are attracted to water of increased salinity by their sense of smell (Tesch 1974; Hain 1975). This ability would be important upon entry in the estuary (Barbin 1998). However, it is not likely that eels could have detected seawater at the study site, $18 \mathrm{~km}$ above the estuary. This is even more doubtful when one considers that eels are found several hundreds of kilometers inland. Movements of eels were correlated with decreases in conductivity. Conductivity of seawater is in the $50000 \mu \mathrm{S} \mathrm{cm}^{-1}$ range (Cox et al. 1970), while values measured in this study were around $200 \mu \mathrm{S} \mathrm{cm}^{-1}$. Differences at the time of activity peaks were approximately $80 \mu \mathrm{S} \mathrm{cm}^{-1}$. Could eels have detected such small changes in conductivity? Electrical conductivity estimates the total amount of dissolved ions in the water. It is mainly controlled by geology (rock composition) but varies in time with precipitations and discharge. Conductivity generally increases from upstream to downstream, as one moves further away from the river source. Fontaine and Koch (1950) report gradients in mineral concentration in freshwater which are possible orientation cues for fish. They also provide convincing evidence that fish are able to perceive such small differences in salinity. Thus, according to Bull (1937) cited by Fontaine and Koch (1950) fish are able to detect salinity differences in the range of 0.06 to 0.45 . If this is so, following such a gradient will guide them towards the estuary. This will be particularly important in low or no-flow areas where eels cannot use currents as one of their orientation cues. Eels from the Certes-99 batch were five to ten times more active than eels caught locally on River Nive. Certes is a reclaimed brackish water marsh (salinity varies between 13 and 35) located on a delta opening onto the Bay of Biscay. This suggests that the 
transfer to freshwater (i.e. River Nive water) induced an even greater urge to migrate in those eels. This may be another indication that eels react strongly to even small changes in salinity. Unfortunately no replicate treatment was done to confirm this conclusion.

Another possible explanation for increased locomotor activity is that eels react to increased turbidity (in terms of darkening of the water) rather than to a particular component in the water. During a telemetry study on Atlantic salmon smolts, downstream migration was triggered "accidentally" during broad daylight by a nearby truck which poured soil into the river (personal observation). There is clearly an advantage in migrating (or foraging) in turbid water for predator avoidance.

Eels in the tap water tank possibly reacted to a drop in $\mathrm{pH}$. Many fish are sensitive to acidic water but in the range 5.0-5.8 for most species (Peterson et al. 1989), which is much lower than the values we observed (drop from 7.5 to 6.9). There is no relationship between conductivity and $\mathrm{pH}$ (Ozeki et al. 1999). The latter reflects the concentration of one particular ion, $\mathrm{H}^{+}$, but does not provide information on the presence of other ions that may affect the electrical conductivity and, therefore, it is not possible to determine from $\mathrm{pH}$ whether there was a simultaneous change in conductivity.

Silver eels, while still in freshwater, are already physiologically adapted to osmoregulate in saltwater. This causes a progressive demineralization as long as they remain in freshwater (Boucher-Firly and Fontaine 1933; Fontaine 1975; Dutil et al. 1987). Silver eels leave freshwater at the time when this phenomenon begins (Fontaine and Koch 1950). A decrease in conductivity, as observed in this study, may further induce the need to reach saltwater. The fact that eels from Certes, which were even further adapted to saltwater, had a stronger reaction compared to freshwater eels supports this interpretation. Once at sea, eels swim continuously except during daylight when they lie passively on the sea floor (Westerberg et al. 2007). The onset of migration of saltwater eels may depend solely upon their physiological state, i.e. the timing of silvering. In freshwater, even if the runs occur in a discrete pattern, the timing of silvering determines the timing of subsequent migration (Durif and Elie 2008). Because silvering is probably initiated by a decrease in temperature and/or photoperiod this would ensure that individuals in a population are synchronized and reach the spawning grounds at the same time.

Acknowledgements. We thank and remember Claude Garaïcoechea for his help and technical assistance. We are also grateful to the EDF staff at the hydroelectric station of Halsou for their collaboration. Thanks to Howard Browman for his helpful suggestions which improved the clarity of the manuscript. We also thank the referees for detailed and helpful comments.

\section{References}

Barbin G.P., Parker, S.J., Mc Cleave J.D., 1998, Olfactory clues play a critical role in the estuarine migration of silver-phase American eels. Environ. Biol. Fishes 53, 283-291.

Batschelet, 1981, Circular statistics in biology. Academic Press

Behrmann-Godel J., Eckmann R., 2003, A preliminary telemetry study of the migration of silver European eel (Anguilla anguilla
L.) in the River Mosel, Germany. Ecol. Freshw. Fish. 12, 196202.

Boëtius J., 1967, Experimental indication of lunar activity in European silver eels, Anguilla anguilla (L.). Medd. Danm. Fisk. Havunders. 6, 1-6.

Boucher-Firly S., Fontaine M., 1933, Rapports existant entre quelques stades de développement de l'Anguille et le point de congélation de son sérum lors du passage en eau de mer. C. R. Scéances Soc. Biol., Paris. 112, 462.

Bruijs M.C.M., Durif C.M.F., 2008, Silver eel migration and behavior. In: van den Thillart G., Dufour S., Rankin C. (Eds.) Spawning migration of European eel - reproduction index, a useful tool for conservation management, Springer, in press.

Cox R.A., McCartney M.J., Culkin F., 1970, The specific gravity/salinity/temperature relationship in natural sea water. DeepSea Res. 17, 679-689.

Durif C., Dufour S., Elie P., 2005, The silvering process of Anguilla anguilla: a new classification from the yellow resident to the silver migrating stage. J. Fish Biol. 66, 1025-1043.

Durif C., Gosset C., Rives J., Travade F., Elie P., 2003, Behavioral study of downstream migrating eels by radio-telemetry at a small hydroelectric power plant. In: Dixon D.A. (Ed.) Biology, Management, and Protection of Catadromous Eels, Bethesda, Maryland, Am. Fish. Soc. Symp. 33, pp. 343-356.

Durif C.M.F., Guibert A., Elie P., 2008, Morphological discrimination of the silvering stages of the European eel. In: Casselman J.M., Cairns D.K. (Eds.) Eels at the edge: science, status, and conservation concerns. Proc. 2003 International Eel Symposium, Bethesda, Maryland, Am. Fish. Soc. Symp. Publ., in press.

Durif C.M.F., Elie P., 2008, Prediction of downstream migration of silver eels in a large river catchment based on commercial fishery data. Fish. Manage. Ecol. 15, 127-137.

Dutil J.D., Besner M., McCormick S.D., 1987, Osmoregulatory and ionoregulatory changes and associated mortalities during the transition of maturing American eels to a marine environment. Am. Fish. Soc. Symp. 1, 175-190.

Edel R.K., 1975, Effect of shelter availability on activity of male silver eels. Helgol. Meersunters. 27, 167-174.

Edel R.K., 1976, Activity rythms of maturing American eels (Anguilla rostrata). Mar. Biol. 36, 283-289.

EPRI 2001, Review and documentation of research and technologies on passage and protection of downstream migrating catadromous eels at hydroelectric facilities. Report No. 1000730, Electric Power Research Institute (EPRI), Palo Alto, CA.

Euston E.T., Royer D.D., Simons C.L., 1997, Relationship of emigration of silver American eels (Anguilla rostrata) to environmental variables at a low head hydro station held in Atlanta, Georgia. In: Mahoney D.J. (Ed.) Proc. International Conference on Hydropower, Atlanta, Georgia, Am. Soc. Civil Engineers (ASCE), Reston, Virginia, pp. 549-558.

Fontaine M., 1975, Physiological mechanisms in the migration of marine and amphihaline fish. Adv. Mar. Biol. 13, 241-355.

Fontaine M., Koch H., 1950, Les variations d'euryhalinité et d'osmorégulation chez les poissons. Leur rapport possible avec le déterminisme des migrations. J. Physiol. 42, 287-318.

Gosset C., Travade F., Durif C., Rives J., Elie P., 2005, Tests of two types of bypass for downstream migration of eels at a small hydroelectric power plant. River Res. Appl. 21, 1095-1105.

Hadderingh R.H., Baker H.D., 1998, Fish mortality due to passage through hydroelectric power stations on the Meuse and Vecht rivers. In: Jungwirth M., Schmutz S., Weis S. (Eds.) Fish Migration and Fish Bypasses, Oxford, Fishing News Books, Blackwell Science, pp. 315-328. 
Hain J.H.W., 1975, The behaviour of migratory eels, Anguilla rostrata, in response to current, salinity and lunar period. Helgol. Meersunters. 27, 211-233.

Haraldstad O., Voellestad L.A., Jonsson B., 1985, Descent of European silver eel, Anguilla anguilla L., in a Norwegian watercourse. J. Fish Biol. 26, 37-41.

Haro A., 2003, Downstream migration of silver-phase anguillid eels. In: Aida K., Tsukamoto K., Yamauchi K. (Eds.) Eel Biology, Tokyo, Springer Verlag, pp. 215-221.

ICES, 2007, Report of the 2007 session Joint EIFAC/ICES Working Group on Eels. Report No. ICES CM 2007 / ACFM, Bordeaux, France.

Lowe R.H., 1952, The influence of light and other factors on the seaward migration of the silver eel (Anguilla anguilla L.). J. Anim. Ecol. 21, 275-309.

McCleave J.D., Jellyman D.J., 2002, Discrimination of New Zealand stream waters by glass eels of Anguilla australis and Anguilla dieffenbachii. J. Fish Biol. 61, 785-800.

Okamura A., Yamada Y., Mikawa N., Tanaka S., Oka H.P., 2002, Exotic silver eels Anguilla anguilla in Japanese waters: seaward migration and environmental factors. Aquat. Living Resour. 15, 335-341.

Ozeki T., Tanaka Y. Fukamizu M., Ogawa N., 1999, Plots of the pH versus electric conductivity of rainwater for evaluating the accuracy of pH measurements. Anal. Sci. 15, 1159-1161.

Peterson R.H., Coombs K., Power J., Paim U., 1989, Responses of several fish species to $\mathrm{pH}$ gradients. Can. J. Zool. 67, 1566-1572.

Schmidt J., 1922, The breeding places of the eel. Philos. Trans. R. Soc. Lond., Ser. B. 211, 179-208.
Sloane R.D., 1984, Preliminary observations of migrating adult freshwater eels Anguilla australis australis Richardson, in Tasmania. Aust. J. Mar. Freshw. Res. 35, 471-476.

Smith R.J.F., 1985, The control of fish migration. Springer-Verlag, Berlin Heidelberg.

Sola C., Giulianini P.G., Ferrero E.A., 1993, Ultrastructural charaterization of the olfactory organ in glass eels, Anguilla anguilla (Osteichthyes, Anguilliformes). Boll. Zool. 60, 253-261.

Tesch F.W., 1974, Influence of geomagnetism and salinity on the directional choice of eels. Helgol. Meersunters. 26, 382-395.

van Ginneken V., Durif C., Balm S.P., Boot R., Verstegen M.W.A., Antonissen E., et al., 2007, Silvering of European eel (Anguilla anguilla $\mathrm{L}$.): seasonal changes of morphological and metabolic parameters. Anim. Biol. 57, 63-77.

Vøllestad L.A., Jonsson B., Hvidsten N.A., Naesje T.F., Haralstad O., Ruud-Hansen J., 1986, Environmental factors regulating the seaward migration of European silver eels (Anguilla anguilla). Can. J. Fish. Aquat. Sci. 43, 1909-1916.

Westerberg H., Lagenfelt I., Svedang H., 2007, Silver eel migration behaviour in the Baltic. ICES J. Mar. Sci. 64, 1457-1462.

Westin L., Nyman L., 1979, Activity, orientation, and migration of baltic eel (Anguilla anguilla L.). Rapp. P.-v. Réun. Cons. Int. Explor. Mer. 174, 115-123.

Winter H.V., Jansen H.M., Bruijs M.C.M., 2006, Assessing the impact of hydropower and fisheries on downstream migrating silver eels, Anguilla anguilla, by telemetry in the River Meuse. Ecol. Freshw. Fish. 15, 221-228. 